\title{
Policy-making for structural reforms in Welsh higher education landscape
}

\author{
CHEPS WORKING PAPER 02/2017 \\ Paul Benneworth. CHEPS (University of Twente) \\ p.benneworth@utwente.nl \\ Nadine Zeeman. CHEPS (University of Twente) \\ n.zeeman@utwente.nl
}

This is the pre-submission draft of the following book chapter:

Zeeman, N., \& Benneworth, P. (2017). Policy-Making for Structural Reforms in the Welsh Higher Education Landscape. In Policy Analysis of Structural Reforms in Higher Education (pp. 245-268). Springer International Publishing. The version of record is available via this link https://link.springer.com/chapter/10.1007/978-3-319-42237-4 12

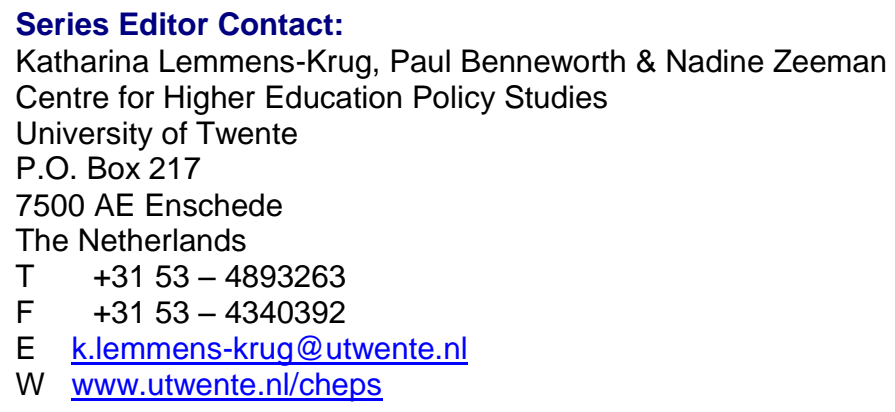




\section{Table of Contents}

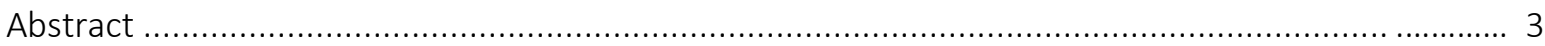

1. Introduction: mergers as structural reforms in Europe............................................................. 4

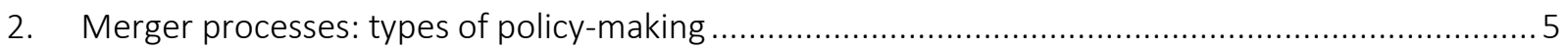

3. Bottom-up co-ordination: lessons from the open method of co-ordiantion.................................. 7

4. The context to the Welsh structural reform process …..........................................................

5. Bottom-up co-ordination: lessons from the open method of co-ordination............................... 12

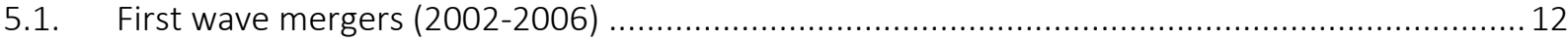

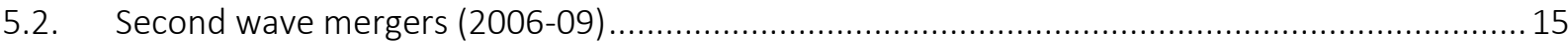

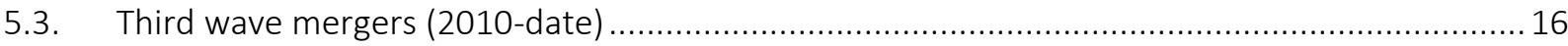

6. Bottom-up initiative in in structural reforms viewed as an open method of co-ordination............ 18

7. Co-ordinating bottom-up mobilisation for effective structural reform ........................................ 21

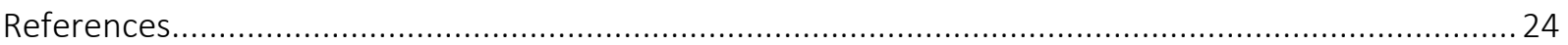




\section{Abstract}

In this working paper we present an analysis of the merger process in Wales in the period from 2002-2012. The mergers were initiated to reduce the overall number of universities as part of an effort to increase the overall competiveness of the Welsh higher education system in the wider United Kingdom higher education system.

The Welsh merger structural reforms have been analysed by using a governance approach to HE mergers. The aim is to understand whether the structural reform process can be understood as functioning as an open method of co-ordination. The OMC can provide a conceptualization of bottom-up driven merger processes. This is certainly the case for countries like the UK where universities have high levels of institutional autonomy. Various elements of the OMC approach can be detected in Welsh merger reforms. The structural reforms provided for strong co-ordination and also strong initiative taken by the universities themselves. It is difficult to determine whether the co-ordinated mergers have been successful. On the one hand, it reduced the overall number of universities. The capacity of the system has improved and the average size of the institutions has increased. On the other hand, the desired end point of six institutions has not been met and the average size of the institutions remains relatively low in the UK context.

Key words: bottom-up coordination, higher education institutions, higher education systems, mergers, open method of coordination, structural reforms, Wales. 


\section{Introduction: mergers as structural reforms in Europe}

Many European countries have undertaken structural reforms of their higher education (HE) systems in Europe, intending to change the overall national higher education landscapes, through fundamental structural changes to the governance, funding, structure and organisation of HE. In this chapter, we particularly focus in the transformations in the interrelationships between higher education institutions (HEIs). Our focus will be the policymaking process in the merger process of Welsh HEIs, within a movement within national HE systems towards institutional association, consolidation and concentration. This movement is driven by the external factors of internationalisation, competition and the economic situation. Revenues are decreasing and competition for international students is increasing.

The most common and visible policy response to globalisation have been increasing the efficiency of the HE system by concentrating (merging) existing already established HEIs. This may involve various forms of associations of HEIs ranging from relatively weak associations, such as consortia, to fully-fledged associations, such as pure mergers (Amaral, 2009, p.13; Barber, Donnelly \& Rizvi, 2013, p.10; Estermann, Bennetot Pruvot, Claeys-Kulik, 2013, p. 4, 12). Our focus here is on the latter, the mergers, as strong forms of association. There have been many mergers within the European Union within national HE systems across many European Union (EU) member states (European Commission, 2014) to create newly consolidated HEIs capable of competing globally (Salmi, 2009, p. 43-44) as we as reducing costs and enabling economies of scale (Pinheiro, Geschwind \& Aarrevaara, 2015, p.1). Policy frameworks for HE reform programmes have been set up that explicitly focus on consolidations and mergers.

In certain systems, mergers have been part of an instrumental top-down system wide organisation, using policy interventions to encourage or oblige HEIs to progress with mergers, whether through financial support or legal compulsion. Several merger experiences have driven arguments that universities themselves can best identify their needs, develop strategies, and explore options and initiating merger processes. The role for policy in this arrangement is providing a framework and structure that enables the HEIs to meet the objectives rather than top-down wide-scale reorganisations imposed by 
governments (Bennetot Pruvot, Claeys-Kulik \& Estermann, 2015b, p. 13, 62). Hence our research question, namely how can governments harness bottom-up knowledge from the expert institutions to shape mergers to produce effective system transformation.

\section{Merger processes: types of policy-making}

In recent years, we can detect a movement within national HE systems towards institutional association, consolidation and concentration. This movement is driven by the external factors of internationalisation, competition and the economic situation. In a large number of European countries, HEIs are facing increasing challenges shaped by globalisation. Income from revenues are decreasing and the competition for international students is increasing. Within this context, national governments are implementing policies to support their HEIs in the globalization processes. The most common and visible policy response to globalisation have been concentration of existing HEIs to improve system efficiency.

Various forms of new university association have been formed to provide these concentration effects. At one end of the spectrum are loose associations such as consortia of similar institutions; a typical middle way approach is exemplified by the creation of federal university systems with distinct colleges under a federal centre, to a pure merger into a single organisational form (Amaral, 2009, p.13; Barber, Donnelly \& Rizvi, 2013, p.10; Estermann, Bennetot Pruvot, Claeys-Kulik, 2013, p. 4, 12). Our focus in this chapter is on mergers, because they are both the most intensive and far-reaching intervention with extensive effects on the HE landscape within national systems, but also they have in the last decade been increasingly popular across a range of HE systems including Finland, Norway, Denmark and France.

The policy-driven restructuring initiatives towards mergers have taken different forms in these European countries. We can detect governance mechanisms at different level, and notably the widespread use of instrumental top-down system-wide organisation. In these systems, several methods aiming at encouragement and obliging the HEIs have been used to reach this, including incentivising institutions to merge by providing them financial support, most visible in the case of Aalto University which received a governmental endowment of 
$€ 500 \mathrm{~m}$ to support the merger. Governments have also introduced legislative reforms to obligate HEIs to cooperate with the merger process. With top-down implementation, the decisive policy-making takes place at the central level. Policy means are clearly defined and include incentives that guide the successful implementation of the merger; they are a traditional hierarchical form of government, and are heavily dependent for their effectiveness on the 'wisdom of policy makers' (Bennetot Pruvot, Claeys-Kulik \& Estermann, 2015b, p. 62-63; Estermann, Bennetot Pruvot, Claeys-Kulik, 2013, p. 12; Gornitzka, Kyvik \& Stensaker, 2005, p. 50). The Danish government decided that a number of mergers should become effective in January 2007. In this example a combination can be found of encouragement and obligation. The Danish government set up an Innovation Fund that rewarded the combination of similar institutions (Amaral, 2009, p. 15; Salmi, 2009, p. 43).

There are some examples of bottom-up reorganisations where HEIs have at their own initiative proposed mergers even in the absence of governmental pressure or other incentives, albeit relatively rare. In some cases, the universities have had to proactively seek approval for those mergers from the public authorities. An example of a bottom-up initiated merger reform can be found in Sweden, where the University College Kalmar and Växjö University voluntarily merged to create the new university Linnaeus University in 2010, financially supported by the Swedish government (Ljungberg \& McKelvey, 2015, p. 68). In these cases, mergers are driven by the individual perceptions of HEIs on their general situation, the competitive challenges they face, and the contribution that the merger can make to that situation (Bennetot Pruvot, Claeys-Kulik \& Estermann, 2015b, p. 62-63; Gornitzka, Kyvik \& Stensaker, 2005, p. 50).

Both approaches to structural reforms, top-down or bottom-up, can be found in the European HE landscape. It has to be noted that in practice 'pure' voluntarily initiated mergers are very rare in practice. Most of the mergers are influenced to some extent by state, since many voluntarily mergers are stimulated by incentives of the state, primarily financial ones (Cai, Pinheiro, Geschwind \& Aarrevaara, 2015, p.5; Pinheiro, Geschwind \& Aarrevaara, 2015, p.2). Even though most structural reforms in HE are government led, the reforms could potentially be organised through co-ordinating bottom-up initiatives emerging from the HEIs themselves. In these instances HEIs position themselves in strategic mergers to 
respond to the challenges of increasing competitions and decreasing funding. HEIs are the central administrators.

\section{Bottom-up co-ordination: lessons from the OMC}

Most of the structural reforms in HE systems in this volume as government driven and follow a top-down approach, i.e. following a governmental, rather than a governance, approach to steering. In a governmental model the decision-maker uses deep insight into the current situation to generate a clear idea of the desirable end point and specifies in detail the policy interventions required. By contrast, in a governance arrangement, the government sets out the direction of travel, the "rules of the game" and incentives to encourage expert actors to participate; experts are in this case those service providers that have the detailed knowledge of the complexities of the particular areas of service being provided. IN a university merger process, where the detailed knowledge about teaching and research is held by the universities themselves, we foresee that there are problems in relying upon the ex-ante wisdom of government to address a single direction of travel. Therefore it is perhaps slightly surprising to see that the majority of mergers appear to have been imposed in ways that seem to demand a certain level of governmental approach in the process.

Conversely, a bottom-up merger policy therefore creates an arena involving internal and external stakeholders engaged in constructive dialogues, discussing both present situation and future actions and scenarios. In this regard, the process leading to merger (or not) is perceived as more relevant than the decision to merge or the results that derive from the merger in the future (Pinheiro, Geschwind \& Aarrevaara, 2015, p.4). An advantage of these voluntary mergers is that they tend to more successful than 'forced' mergers by governments, by allowing for a higher degree of staff involvement which increases the feeling of responsibility for the process (Harman \& Harman, 2003, p. 31-32).

To better understand bottom-up voluntary mergers process, we draw an analogy here with the EU's open method of coordination to coordinate EU member's states policies which are 
formally reserved to those member states. The $\mathrm{OMC}$ is a governance tool based on the EU member states' voluntarily participation. It provides coordination through the dissemination of experiences that provide the incentives for of mutual learning and the sharing of knowledge (Gornitzka, 2005, p.5-6; Humburg, 2008, p. 5). The process that eventually leads to convergence is also characterized by deliberation between the actors involved, sharing information and interests through dialogues. Each member state commits to working towards a collective goals and objectives, although each member state has freedom to determine how the common goals are to be achieved.

Even though the $\mathrm{OMC}$ is based on voluntary cooperation, financial incentives may be provided from the EU budget to stimulate national reforms (Gornitzka, 2005, p. 5-6; Heidenreich, 2009, p. 23; Humburg, 2008, p. 5). We therefore contend that the OMC provides a lens through which to conceptualise bottom-up driven merger processes within a higher education system, certainly in countries like the UK where universities are private bodies with substantial autonomy. We do not wish to overclaim the similarities here with the formal OMC (used for example in the European Education Area and the Bologna process), but it provides a lens to understand how bottom-up co-ordination can still lead to a common direction of travel.

Our approach here is to regard an OMC as a form of system. Systems can be understood as four types of element, namely the sub-systems (actors), the connections/ relationships between the actors (transactions), the architecture of the system (steering vision) and the outcome (the systemic effect). The outcome is the open method of co-ordination that the system as a whole evolves to a desirable endpoint, in this case through the bottom-up involvement of the various actors. The other three system elements in this case are:

- Initiators: these are the universities and the policy-makers who interact, make strategies and allocate resources that lead to the delivery of core higher education functions.

- The regulatory framework: these are particular policy interventions, funding programmes, guidance notes and regulatory instruments that set the 'rules of the game' for the structural reform. 
- The process: the means by which relationships are built and maintained between actors to give an overall steering effect to the final desirable end-point.

It is through this lens that we will look at the Welsh merger structural reform as a means to understand whether this can address the issues raised by using a governmental rather than a governance approach to HE mergers. In this research we want to understand whether this reform process can be understood as functioning as an OMC, leading the actors to a desirable endpoint whilst placing initiative in the hands of the universities themselves. To address this, this chapter draws on a piece of research undertaken - in common with the many contributions in this volume, to the European Commission's SHERDE project. The authors were responsible for the Wales structural reform case study, and as part of that interviewed 11 experts, as well as reviewing a substantive volume of policy literature, some of which appears in the references section. The fieldwork was undertaken in the summer of 2015, and the SHERDE report being completed in September of that year. This case study was produced in the Spring of 2016 drawing upon that evidence base but independently of that initial report.

\section{The context to the Welsh structural reform process}

The Welsh HE sector is relatively new, formally coming into being in 1993 as the result of the Further and Higher Education Act in 1992. This Act made changes in the funding and administration of further education and HE in both England and Wales, and created a separate higher education funding council for Wales: the Higher Education Funding Council for Wales (HEFCW). Prior to the Act, the Welsh HE system formed a coherent subsystem within the UK's funding arrangements, with universities funded latterly by the Universities Funding Council (UFC) and previously the Universities Grants Committee (UGC). At that time, Welsh universities formed only a small share of the UK university system, with one large university, the second largest in the UK, and this was the (collegiate) University of Wales, with three foundation colleges in Aberystwyth, Bangor and Cardiff.

Most of the HEIs established in 1960s and 1970s were themselves formed through mergers between individual educational institutes. The most significant merger prior to 2000 was 
between the University of Wales Institute of Science and Technology (UWIST) and University College, Cardiff (UWIC) in 1988, creating the first institution in Wales comparable to large research-led universities elsewhere in the UK. This merger was to prove extremely beneficial to the Welsh HE system, clearly adding value and stimulating the development of research and innovation in South-East Wales. However, in reality, the merger was driven by a the late 1980s financial crisis, with the (UK) UGC requiring that University College, Cardiff merged with neighbouring institutions to restore some sustainability to their finances (Further and Higher Education Act 1992, p. 46; Gummett, 2015, p. 83; HEFCW, 1991).

HEFCW at the time of its creation functioned as an arm's length body responsible to the national government Welsh Office. All of this changed in 1998-1999, when Wales assumed direct political control over organising and funding its HE system as a consequence of devolution. This devolution redistributed a series of responsibilities to Cardiff to be exercised by the newly elected National Assembly for Wales (WAG) including that for HEFCW. As of 1999, the National Assembly was responsible for the funding of a system comprising 13 HEIs, as shown in with their main characteristics in table 1. (Gallacher \& Raffe, 2013, p. 467-468; Gummett, 2015, p. 83).

Table 1: HEls Wales in 2003 (Source: HEFCW Annual Report 2003-2004, p.11)

\begin{tabular}{|l|l|}
\hline HEI & Total enrolment (all levels, part time and full time) \\
\hline Cardiff University & 19,929 \\
\hline University of Glamorgan & 19,350 \\
\hline University of Wales, Swansea & 11,727 \\
\hline University of Wales, Aberystwyth & 9,835 \\
\hline University of Wales, Bangor & 9,599 \\
\hline University of Wales, Newport & 8,700 \\
\hline University of Wales Institute, Cardiff & 8,594 \\
\hline North East Wales Institute of Higher Education & 6,397 \\
\hline Swansea Institute of Higher Education & 4,974 \\
\hline University of Wales, College of Medicine & 4,144 \\
\hline University of Wales, Lampeter & 3,493 \\
\hline Trinity College, Carmathen & 1,803 \\
\hline Royal Welsh College of Music and Drama & 583 \\
\hline
\end{tabular}


Devolution marked the starting point of Wales' systematic merger, beginning in January 1999, when the Welsh Office, whose powers were subsequently transferred to the WAG in 1999, directed HEFCW to identify possibilities for mergers of universities and to provide recommendations to the new National Assembly future directions of travel. HEFCW's report included the important recommendation that it would be most viable to have 5 to 6 HEIs. HEFCW also suggested that the National Assembly should invite HEIs to engage in discussion with the aim to achieve a strategic and structural reorganisation within the next 3 to 5 years. This report, The Scope for Institutional Mergers at the Higher Educational Level, would later be followed up with three more reports (1999-2002) that again emphasised the unavoidable need for mergers between Welsh HEIs. The strategic context to these reports was HEFCW's view that Wales' HE sector faced a range of challenges in order to adapt and thrive in an increasingly internationalised education environment of the international knowledge economy (GAELWa, 2004, p. 17; Gummett, 2015, p. 84). In concrete terms, the reports identified several challenges that demanded a system restructuring. These challenges are, in summary (a) increased competition from large, efficient organisations in England and elsewhere in Europe (b) a lack of critical mass to invest strategically in new teaching technologies and practices, new strategic research areas and to compete for UK Research Council and European research funding (GAELWa, 2004; HEFCW, 1999; National Assembly for Wales, 2001. p.57)

The Welsh Assembly's Education and Lifelong Leaning Committee's Policy Review of Higher Education (2002) was one of four reports arguing that mergers were inevitable these tensions and stresses in the Welsh HE system. The report foresaw either collaboration or mergers as being the solution, but despite being forewarned that mergers would be unpopular, plumped for the merger option. They proposed using bottom-up mergers as a process to reduce resistance, encouraging mergers between HEIs with similar missions and visions, with clear mutual benefits, underpinned by careful and structured planning. The WAG then published its Report Reaching Higher, which included a strategy for the HE sector in Wales, specifically building upon the Policy Review of Higher Education evidence. WAG agreed with a merger approach, but noted that high levels of university institutional 
autonomy enshrined in the Act made it very difficult for WAG to impose a top-down structure Welsh Assembly Government, 2002, p.7).

\section{Bottom-up co-ordination: lessons from the open method of co-ordination}

The White Paper acknowledged the challenges and the tension confronting Welsh HE, and marked the start of a merger process which at the time of writing has not yet reached the desired end point of 5-6 institutions. In the period from 2002 to 2012, the Welsh Government - with varying degrees of pressure, has sought to facilitate mergers and reshape the sector. Writing in 2015, HEFCW's chief executive for much of the period, Professor Phil Gummett (2015) distinguished three informal phases in this merger history: 2002-2006, 2006-2009 and 2010-2012 (onwards) (Gummett, 2015, p. 85). The process formally began in 2002 with HEFCW launching its the Reconfiguration and Collaboration (R\&C) fund, to finance strategic, substantial and sustainable HEI proposals to either merge, or create crossinstitutional cooperation within research and teaching. HEIs were invited to submit their proposals for further collaborations at the highest level of the institutions, for an October 2002 deadline; all 13 Welsh HEIs were to submit a funding proposal (GAELWa, 2004, p. 19; Gummett, 2015, p. 85). 20 proposals were received of which 10 received support, three were deferred, two referred for consideration and the final five were rejected; the successful 10 included four proposals for mergers and strategic alliances.

\subsection{First wave mergers (2002-2006)}

The merger between Cardiff University and the University of Wales College Medicine initiated in 2003 would later be identified by the Wales Audit Office as one of the three most substantial mergers in Wales. Both institutions appointed new Vice Chancellors positively disposed towards merger in 2001. In January 2005, the merger was achieved with the two HEIs coming together as Cardiff University and by 2006 the merger process was complete (Colman, 2009, p.7, 16; HEFCW, 2010, p.5). Its rationale was allowing the HEIs to pursue internationally recognized high quality research, learning and teaching to benefit Wales and the rest of the world. Both were located in Cardiff: Cardiff University attracted much research funding from private and public sources, although the absence of a medical school reduced 
its opportunities to also attract medical research funding. The University of Wales College Medicine was much smaller and hence financially vulnerable, one of two independent medical schools in the UK, with some teaching delivered by Cardiff University and also some existing research co-operation. There was a good case for merger based on both perceived potential mutual benefits and a strong mutual fit (Colman, 2009, p.16-17; Gummett, 2015, p. 86; HEFCW, 2010, p. 5, 26). The two Vice Chancellors began merger negotiations before formal appointment, and were appointed to give strong merger leadership over the process, listening to both staff and then also later to students to deal with emergent matters (HEFCW, 2010, p. 26-28). The merger was smooth, with most desired outcomes achieved; HEFCW regarded the merger process as a success and an example for others (HEFCW, 2010, p. 3; Parken, 2011, p. 5).

The second proposal concerned exploratory talks between Bangor University and North East Wales Institute of Higher Education (NEWI) (later to become Glyndŵr University in 2008), both located in North Wales. In 2001, Bangor University and NEWI had signed a strategic alliance, and unsurprisingly both universities responded positively to the reconfiguration and collaboration strategy. In 2002 they submitted their proposals to HEFCE, in the first instance to strengthen their strategic alliance and then secondly to establish single university in North Wales, between 2003-2004 and 2005-2006 (Colman, 2009, p. 21; Gummett, 2015, p. 86; Roberts, 2009, p. 120). Despite a smooth start, difficulties arose: neither HEI possessed its own degree awarding powers (DAPs) or official university status, each had very different missions and visions (Bangor emphasising research excellence and NEWI widening access to HE). This mission incompatibility led to the end of merger talks, and in 2004, the University Wales, Bangor decided to apply for DAPs (Colman, 2009, p. 21; Gummett, 2015, p. 86; Roberts, 2009, p. 121), leaving collaboration limited to joint arrangements for staff development (Colman, 2009, p. 21; Gummett, 2015, p. 86).

Thirdly was a proposal from the Universities of Glamorgan (Glamorgan) and Wales Institute, Cardiff (UWIC), both located in South Wales. Both institutions were initially positive, having identified mutual benefits including improving learning resources, efficiency gains and significant opportunities for widening access and participation (GAELWa, 2004, p. 3). But both institutions also submitted other proposals: UWIC submitted five proposal, in four of 
which possible collaborations were proposed with other HEIs, the fifth was for a specific collaboration with University of Wales College, Newport (UWCN). Glamorgan submitted three proposals involving cooperation with other HEIs, one proposal for more specific reconfiguration with the (further education college) Merthyr College and the latter with UWIC to be focused upon the rationalisation of provision (GAELWa, 2004, 20-21). In 2003, an appraisal document was published. This report stated that a merger between the two HEIs should be completed in 2004 , founding a number of committees and groups to discuss the issues prior to merger. Despite meeting regularly during the period from March to June, these groups were unable to resolve the issues, ranging from the method of appointing the new Vice Chancellor to UWIC's fears of being swallowed up by the much larger Glamorgan (GAELWa, 2004, p. 5, 35: Gummett, 2015, p.87). In December 2003, the merger project between the two HEIs was terminated given the apparent then-impossibility of overcome the individual HEI interests (Colman, 2009, p. 30).

The final proposal was between the University of Wales, Aberystwyth and University of Wales Bangor, in West and North-West Wales respectively. Unlike the other mergers, it proposed integrating and strengthening their research in four areas: rural environment, advanced functional materials, catchments and coastal, and medieval and early modern history (Gummet, 2015, p. 88; Parken, 2011, p. 5, 12). In 2002, the two HEIs started discussing this collaboration, engaging at a senior level to discuss a strengthening their collaboration, and thereby strengthening research and teaching. This led to the development of a research partnership that allowed the HEIs to compete with other research groups located elsewhere; its subsequent success led to the creation of a Joint Strategy Board to align their learning and research strategies and to explore further collaborations in teaching and research. In 2005/2006, HEFCW granted the universities funding to proceed with the partnership (Gummet, 2015, p. 88; Parken, 2011, p. 5, 12; "The Aberystwyth-Bangor Strategic Alliance, n.d."). The reasons for opting for strategic collaboration instead of a merger were the strong arguments against merger; the HEIs were 80 miles (120km) apart, with no direct travel connection, had appointed new Vice Chancellors for whom the mergers were not a priority and there were no economies of scale (personal communication, July 16, 2015). 


\subsection{Second wave mergers (2006-09)}

In the second round of reconfiguration and collaboration (2006-2009), HEFCW expressed its ongoing concerns about the Royal Welsh College of Music and Drama, Trinity College, Carmarthen and the University of Wales, Lampeter all small institutions, which remained vulnerable to competition. HEFCW identified several issues for each and this strengthened HEFCW's determination to further reform the HE system and it became more involved in the processes compared to the first round of mergers (Colman, 2009, p. 9; Gummett, 2015, p. 88; HEFCW, 2003). The three HEIs all submitted proposals to the Reconfiguration and Collaboration fund, but those approved did not go far enough with the others being deferred, referred or rejected

The University of Wales, Lampeter (UWL) was a small university, located in West Wales, and HEFCW had several concerns regarding its long term viability; it had invited consultants in 2007 to review UWL's strategy and business model, concluding that UWL faced severe income, management and operational issues. There was no single clear shared vision for UWL and its plans to achieve its objectives were unrealistic. The institution had the ambition to become internationally recognized as the foremost liberal arts university in the UK, yet at the same time lacked the financial wherewithal to achieve this goal. UWL had a vulnerable financial position, with costs exceeding income, itself the result of a decline of incoming full time students and increasing costs. A final major issue was operational and management capacity (HW Corporate Finance, 2008, p. 3-4, 49). UWL's Vice Chancellor agreed a restructuring and of the several options explored, merger appeared the best, the lowest risk with the greatest improvement in its sustainability. Discussions with HEFCW saw UWL in December 2008 initiate collaboration with Trinity College Camarthen, the HEIs received $£ 14.3 \mathrm{~m}$. In 2010, the University of Wales, Lampeter merged with Trinity University College Carmarthen to become the University of Wales, Trinity St David, developing new courses and local engagement, but remaining small with a limited subject offer. HEFCW required the merged HEI to discuss merger with Swansea Institute of Higher Education, and indeed in 2012, the two HEI merged (Colman, 2009, p.9; Gummett, 2015, p.89; "Reconfiguration and collaboration funding highlights, n.d."). 
The second institution merger involved the Royal Welsh College of Music and Drama (RWCMD), the national conservatoire for Wales in Cardiff. In 2004, increasing financial pressures clearly threatened its long term independence, and HEFCW and WAG informed RWCMD that a long-awaited capital investment programme would only be made via the Reconfiguration and Collaboration fund (Capita Consulting, 2012, p. 6; Drowley, Lewis and Brooks, 2013, p. 202). HEFCW proposed that RWCMD approach a larger and suitable experienced partner, initially approaching the nearby Cardiff University. However, this option was explored just two months after Cardiff University had merged with University of Wales College of Medicine. The discussions with Cardiff University ended in 2005 with the two HEIs unable to align their visions and could not agree on the route to be taken (Capita Consulting, 2012, p. 50).

\subsection{Third wave mergers (2010-date)}

Gummett's analysis of the second wave of mergers was of a period in which momentum and progress was lost $(2015$, p. 90). The limits to voluntary merger appeared to have been reached, and therefore the third wave involved an attempt to restore that momentum by steering the universities more directly (Parken, 2011, p. 7; Welsh Assembly Government, 2009 , p.14, 18). There were three mergers in this period, including the aforementioned merger of Trinity St David and Swansea Metropolitan University. Despite previous mergers, there remained unfinished business, with Glyndŵr remaining independent and Swansea resisting a merger into Glamorgan. In 2009, the WAG reviewed HE sector in Wales and concluded that the Welsh HEIs did not collaborate enough in South-East Wales because of high institutional autonomy. In 2010, the position of HEFCW towards institutional autonomy changed, with WAG asking HEFCW to make proposals for collaborations and to provide a clear description of the future funding arrangements for HE. HEFCW developed a blueprint, where stating that interventions were needed to respond to increasing sustainability challenges. The HEFCE blueprint expected that the Wales would have no more than six institutions distributed regionally. and that the distribution of these six HEIs should reflect the needs of the regions. Three mergers were proposed, some uncontroversial, other controversial (HEFCW, 2010b; HEFCW, 2011; Welsh Assembly Government, 2009, p.18-19). 
The uncontroversial recommendation concerned the merger of the University of Wales Trinity Saint David and Swansea Metropolitan University (formerly known as Swansea Institute of Higher Education) in 2012 (see also part 4.2.1). In 2010, the two governing bodies of the HEIs agreed to form a single university. A merger between the two HEIs would improve the options of courses available for students, would increase recourses for teaching and would meet the needs of employers. The process went smoothly and led to a partnership of equals (HEFCW, 2011, p. 3; "Swansea Metropolitan and Trinity Saint David to merge, $\left.2010^{\prime \prime}\right)$.

The first controversial recommendation concerned Glyndŵr University (formerly known as North East Wales Institute of Higher Education (NEWI)), in HEFCW's analysis too specific and lacking long-term sustainability (HEFCW, 2011, p. 18). HEFCW proposed several options to address these challenges, but they met with considerable resistance. The first was to provide HE in Wrexham through local FE colleges under the oversight of the universities in Bangor and Aberystwyth but this faced extensive local opposition as a takeover that threatened Glyndŵr's regional economic contribution (Parken, 2011, p. 9; Welsh Government, 2013, p. 81). Mergers were likewise rejected, and an interim proposal emerged for a federal model compromising Glyndŵr University and Coleg Cambria to improve participation and increase efficiency gains (Welsh Government, 2013, p.115-117). At the time of writing this is still slowly evolving. .

Finally, in South-East Wales, HEFCW had recommended merging the University of Glamorgan (Glamorgan), University of Wales Institute, Cardiff (UWIC) and University of Wales, Newport (UWN) to create a regional metropolitan university comparable to large new universities elsewhere in the UK, thereby ensuring long-term sustainability. In 2012, the Minster of Education and Skills, Leighton Andrews, announced that focussed discussion between the three HEIs and staff and student representatives, making clear that merger was WAG's preferred option (HEFCW, 2011, p.3; Welsh Government, 2012). However, CMU (the new name of UWIC) refused to engage in merger talks, as the Board of Governors did not perceive any possible benefits of merger for their students, staff and for the University as whole. UWIC's chair of governors argued that the HEIs did not have a shared vision and the merger would be significantly complex and would be risky in terms of sustainability. UWIC 
withdrew from these merger talks, and they continued between Glamorgan and UWN at these institutions' own request to the minister. The two HEIs merged in April 2013, with the dissolving of UWN by the Minister (Gummett, 2015, p. 98; "Leighton Andrews scraps plans..., 2012"; Welsh Government, 2014).

\section{Bottom-up initiative in in structural reforms viewed as an open method of co-ordination}

Before adjudging the effectiveness of the long-term approach in terms of whether it has allowed open co-ordination, it is necessary to look at the long-term results. The restructuring of the Welsh HE system has reduced the number of HEIs from 13 to 8 in the period 2004-2015. Table 2 below shows the situation in Wales at the time of writing, the 8 HEIs with their total number of student can be found for the academic year 2014/2015 (Higher Education Statistics Agency, n.d.).

Table 2 Student enrolments by HE provided (2014/2015) (Source: Higher Education Statistics

$$
\text { Agency (HESA)) }
$$

\begin{tabular}{|c|c|c|}
\hline HEI & Notes & $\begin{array}{l}\text { Total enrolment } \\
\text { (all levels, part } \\
\text { time and full time) }\end{array}$ \\
\hline Cardiff University & $\begin{array}{l}\text { Merger of Cardiff University and University } \\
\text { of Wales, College of Medicine }\end{array}$ & 30,480 \\
\hline University of South Wales & $\begin{array}{l}\text { Merger of University of Glamorgan and } \\
\text { University of Wales, Newport. Incorporates } \\
\text { Royal Welsh College of Music and Drama }\end{array}$ & 27,710 \\
\hline Swansea University & $\begin{array}{l}\text { Formerly known as University of Wales, } \\
\text { Swansea }\end{array}$ & 16,020 \\
\hline Cardiff Metropolitan University & $\begin{array}{l}\text { Formerly known as University of Wales } \\
\text { Institute, Cardiff }\end{array}$ & 13,670 \\
\hline Bangor University & $\begin{array}{l}\text { Formerly known as University of Wales, } \\
\text { Bangor }\end{array}$ & 10,765 \\
\hline University of Wales, Trinity Saint David & $\begin{array}{l}\text { Merger of University of Wales, Lampeter, } \\
\text { Trinity University College Carmarthen and } \\
\text { Swansea Metropolitan University }\end{array}$ & 10,425 \\
\hline Aberystwyth University & University of Wales, Aberystwyth & 9,835 \\
\hline Glyndŵr University & $\begin{array}{l}\text { Formerly known as North East Wales } \\
\text { Institute of Higher Education. Glyndwrr } \\
\text { received university status in } 2008 .\end{array}$ & 6,765 \\
\hline
\end{tabular}


Table 3 below summarizes the mergers within each of the three rounds against the four dimensions set out in section 3, namely the actors, the mode of regulation via HEFCW, the process and the structural change (merger or not).

Table 3 Merger processes Wales summarized

\begin{tabular}{|c|c|c|c|c|}
\hline HEls & Initiators & HEFCW & Process & Merger \\
\hline $\begin{array}{l}\text { Cardiff University and University of Wales } \\
\text { College of Medicine }\end{array}$ & VC's both HEls & Facilitator & $\begin{array}{l}\text { Bottom-up structural reform: VC's and governing bodies } \\
\text { engaged in discussion with internal and external } \\
\text { stakeholders }\end{array}$ & Yes \\
\hline $\begin{array}{l}\text { University of Wales, Bangor and North East } \\
\text { Wales Institute of Higher Education }\end{array}$ & $\begin{array}{l}\text { VC of Bangor } \\
\text { and Principal of } \\
\text { NEWI }\end{array}$ & Facilitator & $\begin{array}{l}\text { Bottom-up structural reform: positive response towards } \\
\text { reconfiguration and two proposals submitted to } \\
\text { HEFCW. No merger, because the mission/visions could } \\
\text { not be aligned. }\end{array}$ & No \\
\hline $\begin{array}{l}\text { University of Glamorgan and University of } \\
\text { Wales Institute, Cardiff }\end{array}$ & Both HEls & Facilitator & $\begin{array}{l}\text { Bottom-up structural reform: jointly appraisal } \\
\text { document informed by committees. Involvement of } \\
\text { committees, working groups and public. No merger } \\
\text { because issues could not be solved. }\end{array}$ & No \\
\hline $\begin{array}{l}\text { University of Wales, Aberystwyth and } \\
\text { University of Wales, Bangor }\end{array}$ & Senior level HEls & Facilitator & $\begin{array}{l}\text { Bottom-up structural reform: analysis of senior level } \\
\text { and set up of Joint Strategy Board. No merger, but } \\
\text { strategic collaboration because strong arguments } \\
\text { against merger. }\end{array}$ & No \\
\hline $\begin{array}{l}\text { University of Wales Lampeter and Trinity } \\
\text { College, Carmarthen }\end{array}$ & $\begin{array}{l}\text { Consultants } \\
\text { HEFCW and VC } \\
\text { UWL }\end{array}$ & Interventionist & $\begin{array}{l}\text { Combination bottom-up/top-down: HEFCW asked } \\
\text { consultants to review UWL. Merger best medium term } \\
\text { solution to issues. UWL advised to merge. }\end{array}$ & Yes \\
\hline $\begin{array}{l}\text { Royal Welsh College of Music and Drama } \\
\text { and Cardiff University }\end{array}$ & $\begin{array}{l}\text { HEFCW and } \\
\text { RWCMD }\end{array}$ & Interventionist & $\begin{array}{l}\text { Combination bottom-up/top-down: HEFCW required } \\
\text { RWCDM to merge with suitable partner. HEls could not } \\
\text { align visions and agree on further steps. }\end{array}$ & No \\
\hline $\begin{array}{l}\text { Royal Welsh College of Music and Drama } \\
\text { and University of Glamorgan }\end{array}$ & $\begin{array}{l}\text { HEFCW and } \\
\text { RWCMD }\end{array}$ & Interventionist & $\begin{array}{l}\text { Combination bottom-up/top-down: HEFCW required } \\
\text { RWCDM to merge with suitable partner. }\end{array}$ & Yes \\
\hline $\begin{array}{l}\text { University of Wales Trinity Saint David and } \\
\text { Swansea Metropolitan University }\end{array}$ & HEFCW & Explicit & $\begin{array}{l}\text { Top-down: HEFCW attached condition to earlier } \\
\text { funding that UWTSD should try to merge with Swansea } \\
\text { Institute of Higher Education. }\end{array}$ & Yes \\
\hline $\begin{array}{l}\text { Glyndŵr University, Bangor University, } \\
\text { Aberystwyth University }\end{array}$ & HEFCW & Explicit & $\begin{array}{l}\text { Top-down: HEFCW proposed structural partnerships. } \\
\text { Met opposition of local stakeholders. }\end{array}$ & No \\
\hline $\begin{array}{l}\text { University of Glamorgan, University of } \\
\text { Wales Institute, Cardiff and University of } \\
\text { Wales, Newport }\end{array}$ & HEFCW & Explicit & $\begin{array}{l}\text { Top-down: HEFCW to create a metropolitan university. } \\
\text { UWIC pressured to merge, but stayed autonomous. }\end{array}$ & No \\
\hline
\end{tabular}

The first round of mergers can be regarded as following an open method of co-ordination, creating governance by the voluntary participation of actors, whilst the remainder were not. Within an OMC, common objectives are determined, but the means to achieve these goals are diverse and actors are free to decide how the common goals are to be achieved. The process to reach convergence is characterised by communication, negotiation and cooperation to share information and interests. Despite the voluntary participation of actors, a financial 
stimulus is present to stimulate reforms (Gornitzka, 2005, p. 5-6; Heidenreich, 2009, p. 23; Humburg, 2008, p. 5).

In the first merger round, where four proposals were approved for funding, we can detect elements of an OMC. HEFCW recommended mergers of Welsh HEIs to address the challenges requiring a restructuring of the HE system. The WAG agreed that mergers were necessary and also agreed with how these mergers should come into being. Mergers should be initiated bottom-up, be mutually beneficial and be planned carefully and structured. In 2002, the RCF had been launched by HEFCW to finance the proposals of further collaboration and mergers submitted by the HEIs (GAELWa, 2004, p. 17, 19; Gummett, 2015, p. 84-85; Welsh Assembly Government, 2002, p.7). As we see, a common objective has been determined (mergers), the means to achieve this objective is up to the HEI (means are diverse) and a financial stimulus is present (RCF). However, in the end only one proposal succeeded, , between Cardiff University (CU) and the University of Wales College Medicine (UWCM).

This merger process includes several elements of an OMC. The proposal to merge was initiated by the HEIs themselves: the VCs of both institutions who favoured a merger and proposed joint leadership of the merger. Both VCs perceived mutual benefits of a merger. Internal and external stakeholders, including staff and students, has been involved in the process towards a merger and afterwards when the merger had been completed. The process has been one of cooperation and discussion. The merger process has been very effective and HEFCW set the merger as an example for other HEIs (HEFCW, 2010a, p. 3, 2628).

The three other proposals did not lead to a merger. The merger between Bangor University and North East Wales Institute of Higher Education (NEWI) failed because the HEIs could not align their missions and visions. Nevertheless, the HEIs have engaged in closer collaborations regarding joint arrangements for staff development (Colman, 2009, p. 21; Gummett, 2015, p. 86; Roberts, 2009, p. 121). The second proposal that did not lead to a merger is the one from the University of Glamorgan (Glamorgan) and University of Wales Institute, Cardiff. The two HEIs explored options for a merger and identified mutual benefits. Committees and groups have been set up to discuss the issues that needed to be resolved 
before a merger could take place. The individual interests could not be solved and led to the termination of the merger project (Colman, 2009, p. 30; GAELWa, 2004, p. 5, 35: Gummett, 2015, p.87). The final proposal reived by HEFCW came from the University of Wales, Aberystwyth and University of Wales Bangor. Their proposal focused on strengthening their collaboration, which has resulted into strategic collaboration in teaching and research. The HEIs did not merge, because of strong arguments against as merger (Gummet, 2015, p. 88; Parken, 2011, p. 5, 12; "The Aberystwyth-Bangor Strategic Alliance, n.d.").

Based on the experiences and results in the first phase of mergers, we argue that an OMC can be effective in structural reforms. The processes resulted into one merger and in two cases HEIs have engaged in closer (strategic) collaborations. The only exception is the case of Glamorgan and UWIC where a merger did not take place. In this instance, the HEIs engaged in committees and groups to discuss the issues showing up, but despite these considerable efforts, no merger had been taken place. The mutual benefits could not exceed the individual interests of the HEIs.

\section{Co-ordinating bottom-up mobilisation for effective structural reform}

Our research question was whether it was possible to design a policy instrument for structural reforms in higher education that provides for strong co-ordination but also strong initiative to be taken by the universities themselves. Viewed as an $\mathrm{OMC}$ approach seeking to harness the bottom-up knowledge of the universities, we can see the various systems elements at play here. The main actors are the universities, the funding council and then at a degree of distance the WAG. Within the universities it was the university leaders that were critical to the process, and in the Wales case, their willingness to view merger as something to which they were willing to devote their leadership energies. What also emerged as important actors in the process were local stakeholders, in particular in the case of more controversial mergers. In this case, the Welsh Assembly members for local constituents were important in articulating these local views, and local media was also important in relating what local communities believed. The ways these different views intersected were important for providing the enthusiasm and momentum within universities to drive forward 
merger, or indeed by the decision by UWIC to withdraw from the merger talks against the strong direction of the WAG.

The most difficult of these to determine is the final point, that of a successfully co-ordinated merger. The most obvious point to make here is that the merger process has achieved a positive outcome, in that it reduced the overall number of institutions, whilst avoiding an institutional failure. Clearly, the HE system in Wales is closer to the vision at the start of the process in terms having a long-term sustainability. The system has also increased its capacity, so the fewer institutions that exist are generally trusted by WAG to invest public funding in a prudent way and be able to deliver continuous improvement for the benefit of Wales as a whole. Average institution size has increased, but there remains a strong degree of diversity in the system. There remains a mix of large and small institutions, a mix of teaching and research intensive institutions, and there are a institutions in the three main residence areas of Wales, namely the South East, the South West and north east. There was a natural evolution in the process, from a more voluntary approach to a more driven approach that ensured that institutional autonomy was respected whilst simultaneously providing co-ordination. The process has also reached a natural end point, with little further appetite for institutional reconfiguration (excepting Glyndŵr).

But the approach has also not delivered all the desired outcomes despite having delivered a successful and apparently sustainable structural shift. Although there has been a reduction in the number of institutions, it is not clear that this has led to a qualitative improvement in their research and teaching performance (acknowledging the counter-argument that at least Wales's position has not further deteriorated). The desired endpoint, the six institutions, has not been delivered, and the average size of institution remains relatively low in a UK context. It is not clear that there has not been a residualizing effect of the way the process has played out, leaving the more difficult mergers until the end of the process. This has potentially had the effect of preventing mergers that would have been optimum for the system as a whole but which would have spread the benefits out differently between the strong and weak institutions, the potential 'Matthew effect'. This makes it difficult to say with any degree of certainty whether it made more sense for Wales to use this open method rather than to simply impose it in a top-down way from the start. Nevertheless, there seems to be value in 
looking in more detail at ways of steering structural reforms through bottom-up processes rather than firstly developing an ideal type blue print, and then devoting all effort to realising the desired outcome. 


\section{References}

Amaral, A. (2009). Recent Trends in European Higher Education. Available online at http://www.a3es.pt/sites/default/files/9.\%20Tokyio\%20seminar.pdf

Barber, M., Donnelly, K., \& Rizvi, S. (2004). AN AVALANCHE IS COMING: Higher education and the revolution ahead. Available online at http://med.stanford.edu/smili/support/FINAL\%20Avalanche\%20Paper\%20110313\%20\%282 \%29.pdf

Bennetot Pruvot, E., Claeys-Kulik, A., \& Estermann, T. (2015a). Define project: Designing Strategies for Efficient Funding of Higher Education in Europe. Available online at http://www.eua.be/Libraries/publications-homepagelist/DEFINE_Thematic_Report_2_University_Mergers_in_Europe_final

Bennetot Pruvot, E., Claeys-Kulik, A., \& Estermann, T. (2015b). Define project: Designing Strategies for Efficient Funding of Universities in Europe. Available online at http://www.eua.be/Libraries/publications-homepage-list/designing-strategies-for-efficientfunding-of-universities-in-europe.pdf?sfvrsn=4

Cai, U., Pinheiro, R., Geschwind, L., \& Aarrevaara, T. (2016): Towards a novel conceptual framework for understanding mergers in higher education. European Journal of Higher Education, 6 (1), 724. DOI: $10.1080 / 21568235.2015 .1099457$

Colman, J. (2009). Collaboration between Higher Education Institutions. Available online at http://dera.ioe.ac.uk/11694/7/Collaboration_between_HE_institutions_Eng_Redacted.pdf

Education and Lifelong Learning Committee (2002). Policy Review of Higher Education. Available online at http://www.assembly.wales/Laid\%20Documents/Education\%20and\%20Lifelong\%20Learning \%20Committee\%20Report\%20Policy\%20Review\%20of\%20Higher\%20Education\%20\%28Mai n\%20Text\%29\%20-\%20LD-14012002-24467/bus-GUIDE3C441D400007D6EC0000415000000000-English.pdf

Estermann T, Bennetot Pruvot, E., Claeys-Kulik, A. (2013). Define Interim Report: Designing strategies for efficient funding of higher education in Europe. Available online at http://www.eua.be/Libraries/publication/DEFINE_final

European Commission (2014). KEY OUTCOMES - Country Focus Workshop "Changing the higher education landscape: specialisation, consolidation and territorial development" - Riga, 3-4 April 2014. Available online at

http://ec.europa.eu/education/policy/strategic-framework/expert-groups/documents/reportspecialisation-consolidation-development_en.pdf

Further and Higher Education Act 1992 (1992). Retrieved from http://www.legislation.gov.uk/ukpga/1992/13/pdfs/ukpga_19920013_en.pdf 
GAELWa (2004). Report to the accounting offices of the Higher Education Funding Council for Wales: Review of the terminated merger discussion between the University of Wales Institute, Cardiff and the University of Glam organ. Available online at https://www.hefcw.ac.uk/documents/policy_areas/strategic_change/Review\%20of\%20the\%2 0Terminated\%20Merger\%20Discussions\%20Between\%20UWIC\%20and\%20the\%20Universit y\%20of\%20Glamorgan.pdf

Gallacher, J.j \& Raffe, D. (2013). Higher Education policy in post-devolution UK: more convergence than divergence? Journal of Education Policy, 27(4), 467-490. DOI:

$10.1080 / 02680939.2011 .626080$

Gornitzka, A. (2005). Exploring the EU Open Method of Co-ordination. Paper for the Workshop 'The Open Method of Co-ordination - Risks and Chances for European Environmental Policy', 22 March 2004, Brussels. Available online at http://eucenter.wisc.edu/OMC/Papers/Other/environment.pdf

Gornitzka, A., Kyvik, S., \& Stensaker, B. (2005). Implementation Analysis in Higher Education. A. Gornitzka, M. Kogan \& A. Amaral (Eds.), In Reform and Change in Higher Education (pp. 35-56). Springer Dordrecht. DOI: 10.1007/1-4020-3411-3

Gummett, P. (2015). Reorganising the Welsh University System. In A. Curaj, L. Georghiou, J. Cassingena Harper \& E. Egron-Polak (Eds.), Mergers and Alliances in Higher Education: International Practice and Emerging Opportunities (pp. 81-104). Springer Cham Heidelberg New York Dordrecht London. DOI: 10.1007/978-3-319-13135-1

Harman, G., \& Harman, K. (2003). Institutional Mergers in Higher Education: Lessons from International Experience. Tertiary Education and Management, 9(1), 28-44. DOI: 10.1023/A:1022261409801

HEFCW (2003). Reconfiguration and Collaboration Fund W03/65HE. Available online at https://www.hefcw.ac.uk/documents/publications/circulars/circulars_2003/W0365HE.pdf

HEFCW (2010). Evaluation of the impact of the merger of Cardiff University and the University of Wales College Of Medicine: Final report. Available online at http://www.hefcw.ac.uk/documents/policy_areas/strategic_change/cuuwcm\%20merger\%20final\%20evaluation\%20report\%20june\%202010.pdf

HEFCW Annual Report 2003-2004 (n.d.). Retrieved from https://www.hefcw.ac.uk/documents/publications/corporate_documents/Annual\%20Report/ HEFCW\%20Annual\%20Report\%202003-04\%20English.pdf

Heidenreich, M. (2009). The Open Method of Coordination: a pathway to the gradual transformation of national employment and welfare regimes. In M. Heidenreich \& J. Zeitlin (Eds.), Changing European Employment and Welfare Regimes: The influence of the open method of coordination on national reforms (pp. 10-36). Routledge.

Higher Education Statistics Agency (HESA) (n.d.). Statistical First Release 224. Available online at https://www.hesa.ac.uk/stats 
Humburg, M. (2008). The Open Method of Coordination and European Integration: The Example of European Education Policy. Available online at http://www.polsoz.fuberlin.de/polwiss/forschung/international/europa/arbeitspapiere/2008-

8_Humburg_OpenMethodofCoordination.pdf

Parken, A. (2011). A review of higher education collaborations across Wales: context and current picture. Available online at http://www.lfhe.ac.uk/filemanager/root/site_assets/research_resources/research/series_3/S3 -1\%20Parken\%20-\%20Review\%20of\%20HE\%20Collaborations\%20in\%20Wales\%20\%20Context.pdf

Pinheiro, R., Geschwind, L., \% Aarrevaara, T. (2015). Mergers in higher education. European Journal of Higher Education. DOI: 10.1080/21568235.2015.1099455

Roberts, D. (2009). Bangor University 1884-2009. Retrieved from https://books.google.nl/books?id=8nuvBwAAQBAJ\&hl=nl\&source=gbs_navlinks_s

Salmi, J. (2009). The Challenge of Establishing World-Class Universities. Available online at http://siteresources.worldbank.org/EDUCATION/Resources/278200-1099079877269/5476641099079956815/547670-1237305262556/WCU.pdf

The National Assembly for Wales (2001). The Learning Country: a Paving Document. A Comprehensive Education and Lifelong Learning Programme to 2010 in Wales. Available online at http://www.educationengland.org.uk/documents/pdfs/2001-learning-country-wales.pdf

The Aberystwyth-Bangor Strategic Alliance (n.d.).Retrieved from http://aberbangorstrategicalliance.ac.uk/history.php.en

Welsh Assembly Government (2002). Higher Education and the Learning Country: A Strategy for the higher education sector in Wales. Available online at http://gov.wales/dcells/publications/policy_strategy_and_planning/furtherandhighereducation /reaching/reachinghighere.pdf?lang=en 
The Center for Higher Education Policy Studies (CHEPS) is a research institute (WHW, Article 9.20) located in the Faculty of Behavioural and Management Sciences within the University of Twente, a public university established by the Dutch government in 1961. CHEPS is a specialized higher education policy centre that combines basic and applied research with education, training and consultancy activities. 